\title{
Isolation and characterization of a human cementocyte-like cell line, HCY-23
}

\author{
Amanda Bandeira de ALMEIDA(a) \\ Elis Janaína Lira dos SANTOS(a) \\ Gabriel Flores ABUNA ${ }^{(b)}$ \\ Cristiane Salmon RIBEIRO(a) \\ Márcio Zaffalon CASATI(a) \\ Karina Gonzales Silvério RUIZ(a) \\ Francisco Humberto NOCITI \\ JUNIOR(a) $^{(0)}$ \\ (a) Universidade Estadual e Campinas - \\ Unicamp, Faculty of Dentistry, Periodontics \\ Dentistry, Piracicaba, SP, Brazil. \\ (b) Universidade Estadual e Campinas - \\ Unicamp, Faculty of Dentistry, Dental \\ Materials, Piracicaba, SP, Brazil.
}

Declaration of Interests: The authors certify that they have no commercial or associative interest that represents a conflict of interest in connection with the manuscript.

\section{Corresponding Author:}

Amanda Bandeira de Almeida

E-mail: amandabandeiradealmeida@gmail.com

hitps://doi.org/10.1590/1807-3107bor-2019.vol33.0058

Submitted: November 26, 2018

Accepted for publication: May 14, 2019

Last revision: June 10, 2019
Abstract: Cementum is the mineralized tissue covering the tooth root that functions in tooth attachment and post-eruptive adjustment of tooth position. It has been reported to be highly similar to bone in several respects but remains poorly understood in terms of development and regeneration. Here, we investigate whether cementocytes, the residing cells in cellular cementum, have the potential to be protagonist in cementum homeostasis, responding to endocrine signals and directing local cementum metabolism. Cells from healthy erupted human teeth were isolated using sequential collagenase/EDTA digestions, and maintained in standard cell culture conditions. A cementocyte-like cell line was cloned (HCY-23, for human cementocyte clone 23), which presented a cementocyte compatible gene expression signature, including the expression of dentin matrix protein 1 (DMP1), sclerostin (SOST), and E11/gp38/podoplanin (E11). In contrast, these cells did not express the odontoblast/dentin marker dentin sialoprotein (DSPP). HCY-23 cells produced mineral-like nodules in vitro under differentiation conditions, and were highly responsive to inorganic phosphate (Pi). Within the limits of the present study, it can be concluded that cementocytes are phosphate-responsive cells, and have the potential do play a key role in periodontal homeostasis and regeneration.

Keywords: Dental Cementum; Gene Expression; Cell Culture Techniques.

\section{Introduction}

Dental cementum, a mineralized tissue covering the tooth root, is formed in acellular and cellular types. ${ }^{1}$ Acellular cementum (acellular extrinsic fiber cementum, or primary cementum) has been described as a critical factor for tooth attachment and covers the most coronal area of the tooth root. In contrast, cellular cementum (cellular intrinsic fiber cementum, or secondary cementum) has been proposed to play a role in post-eruptive adjustment of tooth position, ${ }^{1}$ and is located at the apical and furcation regions of roots. During cellular cementum development, cementoblasts secrete a layer of unmineralized extracellular matrix (ECM), called cementoid, and as cementoid deposition progresses, cementoblasts might be entrapped in the ECM and become cementocytes. Like bone, dental cementum ECM is primarily composed of collagen (predominantly type I and smaller 
amounts of types III, IV, V, XI, and XII), several noncollagenous proteins, including bone sialoprotein (BSP) and osteopontin (OPN), and proteoglycans, such as biglycan (BGN) and decorin (DCN) ${ }^{2,3}$ Unlike bone, dental cementum is non-innervated, avascular, and grows by apposition with no apparent physiological capacity for remodeling or turnover. While it is recognized that dental cementum regeneration is possible, current clinical strategies to regenerate the periodontal tissues often lack a biologic basis for treatment and have unpredictable outcomes with limited regeneration, especially for dental cementum. ${ }^{4}$ Studies using transgenic animals have identified novel regulators of cementogenesis, $5,6,7$ and comparative proteomic analysis of human dental cementum versus alveolar bone identified differentially expressed proteins associated with potential physiological differences between these two tissues. ${ }^{8,9}$ Although important progress has been made with regards to the understanding of dental cementum development, currently it is clear that a significant barrier to improved periodontal regenerative therapies is that cementum remains poorly understood.

Cementocytes, apparently terminally differentiated cells, are part of a select group of specialized cells that also include osteocytes. Although osteocytes comprise more than $95 \%$ of skeletal cells, they were just recently revealed as key regulators of bone homeostasis and remodeling, acting as mechanosensors, and direct endocrine regulators of mineral metabolism. ${ }^{10}$ A question may be posed whether the cementocyte is a dynamic actor in cementum in comparable fashion with the osteocyte in the skeleton, responding to changing tooth functions and endocrine signals, as well as actively directing local cementum metabolism. Here, we modified a previously reported protocol ${ }^{11}$ to obtain a cementocyte-like cell line from human teeth. Once these human cementocyte (HCY)-23 clonal cells were established, they were characterized regarding their gene expression signature and potential to produce mineral nodules in vitro. In addition, as it is well established that dental cementum is highly sensitive to phosphate metabolism, ${ }^{12,13,14,15}$ we examined the effect of inorganic phosphate (Pi) on HCY-23 behavior.

\section{Methodology}

\section{Biological samples}

Completely erupted teeth (third molars and $1^{\text {st }}$ upper premolars) of eleven subjects (three males and eight females, aged 14 to 30 years), with no clinical signs of caries and/or periodontal disease, were collected. Teeth extractions were performed at the School of Dentistry following a local IR-approved protocol (466/12 - CAAE \# 42930915.9.0000.5418). Systemically healthy subjects (non-smokers, with no history of systemic medication in the last 6 months and/or pregnancy) provided written informed consent to participate in this study, and the study was performed between 2014 and 2016. Following tooth extraction, soft connective tissues adhering to the tooth surfaces were carefully scraped off using a sterile curette, and discarded. Teeth were then rinsed several times in sterile phosphate buffered saline (PBS - Gibco BRL, Life Technologies, USA), placed in biopsy medium composed of minimum essential Eagle medium alpha modification ( $\alpha$-MEM, Gibco, Life Technologies, USA) supplemented with $10 \%$ fetal bovine serum, 250 $\mathrm{mg} / \mathrm{mL}$ gentamicin sulfate, $5 \mathrm{mg} / \mathrm{mL}$ amphotericin $\mathrm{B}$, and $1 \%$ penicillin/streptomycin (Gibco, Carlsbad, USA), and transferred to the laboratory facilities to be processed for cementocyte isolation.

\section{Cell culture and cloning}

Extracted teeth were removed from the biopsy medium and their root's apical portion detached for cementocyte isolation from the cellular dental cementum. Periodontal ligament and pulp tissues were eliminated from the root fragments by enzymatic digestion with $300 \mathrm{U} / \mathrm{mL}$ type I collagenase (Sigma-Aldrich, St. Louis, USA) for 30 minutes at $37^{\circ} \mathrm{C}$ (3x). Procedures used for cementocytes enzymatic isolation are outlined in Table 1. Obtained cells were cultured in standard medium ( $\alpha$-MEM with 10\% FBS and antibiotics), which was changed every 3 days to obtain sufficient cell number for single cell cloning. All obtained clones (115) were assessed regarding their gene expression profile and only one clone with the expected signature (HCY-23, for human cementocyte clone 23), e.g., $\mathrm{DMP1}^{+}, \mathrm{SOST}^{+}, \mathrm{E}^{1} 1^{+}, \mathrm{DSPP}$, was used for further characterization. Cells between the second 
Table 1. Description of the procedures used for isolating a human-derived cementocyte-like cell line.

\begin{tabular}{|c|c|}
\hline Step 1 & $\begin{array}{l}\text { Teeth extracted }(n=13) \text {, quickly rinsed in saline, and kept in biopsy medium ( } \alpha \text {-MEM added with } 10 \% \text { fetal bovine serum, } \\
\qquad 250 \mathrm{mg} / \mathrm{mL} \text { gentamicin sulfate, } 5 \mathrm{~m} / \mathrm{mL} \text { amphotericin } B \text { ) at room temperature. }\end{array}$ \\
\hline Step 2 & $\begin{array}{l}\text { Once at the lab, soft connective tissue adhering to the tooth surfaces were scraped off using a sterile curette, and the apical } \\
\text { portions of teeth were dissected and used for cementocyte isolation from the cellular dental cementum. }\end{array}$ \\
\hline Step 3 & $\begin{array}{l}\text { Additional removal of PDL and pulp tissues from tooth root fragments was achieved by enzymatic digestion }(300 \mathrm{U} / \mathrm{mL} \text { type I } \\
\left.\text { collagenase for } 30 \text { minutes at } 37^{\circ} \mathrm{C}\right) \text {, and supernatant was discarded. }\end{array}$ \\
\hline Step 4 & $\begin{array}{l}\text { Tooth root fragments were subjected to }(3 \mathrm{x}) \text { serial digestions (collagenase } \mathrm{A}, 300 \mathrm{U} / \mathrm{mL} \text { and EDTA, } 5 \mathrm{mM} / 0.1 \% \mathrm{BSA} \text {, for } \\
\qquad 20 \text { minutes each at } 37^{\circ} \mathrm{C} \text { ), and the supernatant was discarded. }\end{array}$ \\
\hline Step 5 & $\begin{array}{c}\text { Tooth fragments were subjected to }(9 \mathrm{x}) \text { serial digestion cycles of collagenase } \mathrm{A}(300 \mathrm{U} / \mathrm{mL}) \text { and } \mathrm{EDTA}(5 \mathrm{mM}, \mathrm{pH}=7.4) \\
\text { for } 25 \text { minutes each, under agitation, at } 37^{\circ} \mathrm{C} \text {, in order to allow cementocyte release from the cementum matrix, and } \\
\text { supernatants plated in biopsy media. Additionally, tooth fragments were rinsed with } \mathrm{HBSS} \text { at } 37^{\circ} \mathrm{C}(3 \mathrm{x}) \text { and cultured in } \\
\text { biopsy culture medium. }\end{array}$ \\
\hline Step 6 & $\begin{array}{c}\text { Cell outgrowth monitored and } \mathrm{DMP1}{ }^{+} \text {heterogeneous populations were subcloned. A single clone, } \mathrm{HCY}-23 \text {, exhibiting a } \\
\text { cementocyte-like gene expression signature, was used for the subsequent studies. }\end{array}$ \\
\hline
\end{tabular}

and sixth passages were used for the experiments, which were always performed in triplicate.

\section{Gene expression procedures}

Total RNA was obtained using the RNeasy system (Qiagen, Valencia, USA) following the manufacturer's recommendations, and complimentary DNA (cDNA) synthesized from $1 \mu \mathrm{g}$ of total RNA (Transcriptor First Strand cDNA Synthesis Kit, Roche Diagnostic Co., Mannheim, Germany), following the recommended protocol. Primer sequences were obtained with the LightCycler ${ }^{\circledR}$ Probe Design Software 2.0 (Roche Diagnostics GmbH, Germany) and are listed in Table 2. Quantitative real-time PCR (qPCR) reactions were optimized for each primer and water was used as a negative control for the reactions. qPCR reactions were performed using the SYBR Green System (FastStart Essential DNA Green Master; Roche Diagnostic Co., Indianapolis, USA) on the LightCycler 480 instrument (Roche Diagnostics GmbH, Netherland).

\section{Immunofluorescence analysis}

In order to determine the morphology of HCY-23 cells, Phalloidin 488 and Sy to Green were used to stain the nucleus and cytoskeleton, respectively, and the images were obtained in a confocal microscope. Briefly, HCY-23 cells were seeded in glass slides at a density of $2 \times 10^{4}$ cells per slide and cultured in DMEM medium supplemented with FBS 10\% for 24 hours. After 24 hours, cells culture medium was removed, and after three washes with phosphate-buffered
Table 2. Primers sequences.

\begin{tabular}{|c|c|}
\hline \multicolumn{2}{|l|}{ GAPDH } \\
\hline Forward & $5^{\prime}$ - AGCCACATCGCTCAGACAC -3' \\
\hline Reverse & 5' - GCTGTACTCGGACACGTCTTT -3' \\
\hline \multicolumn{2}{|l|}{ SOST } \\
\hline Forward & 5' - AGCTGGAGAACAACAAGACCA -3' \\
\hline Reverse & 5' - GCTGTACTCGGACACGTCTTT -3' \\
\hline \multicolumn{2}{|l|}{ E11 } \\
\hline Forward & 5'- AAATGTCGGGAAGGTACTCG -3' \\
\hline Reverse & 5'- AGGGCACAGAGTCAGAAACG -3' \\
\hline \multicolumn{2}{|l|}{ DSPP } \\
\hline Forward & 5'- GCAACATGCTGATGGGAAGA -3' \\
\hline Reverse & 5'-TTTACCTTCGTTGCCTTTCC -3' \\
\hline \multicolumn{2}{|l|}{ OPG } \\
\hline Forward & 5'- GAAGGGCGCTACCTTGAGAT -3' \\
\hline Reverse & 5'- GCAAACTGTATTTCGCTCTGG -3' \\
\hline \multicolumn{2}{|l|}{ DMP1 } \\
\hline Forward & 5'- TTCTTTGTGAACTACGGAGGGTA -3' \\
\hline Reverse & 5'- CAGGATAATCCCCAAAGGGAAC -3' \\
\hline \multicolumn{2}{|l|}{ OCN } \\
\hline Forward & 5'- AGCTCAATCCGGACTGT -3' \\
\hline Reverse & 5'-GGAAGAGGAAGAAGGT -3' \\
\hline \multicolumn{2}{|l|}{$A L P L$} \\
\hline Forward & 5' - CCTGCCTTACTAACTCCTTAGTGC -3' \\
\hline Reverse & 5' - CGTTGGTGTTGAGCTTCTGA-3' \\
\hline \multicolumn{2}{|l|}{ OPN } \\
\hline Forward & 5'- GAGGGCTTGGTTGTCAGC -3' \\
\hline Reverse & 5'- CAATTCTCATGGTAGTGAGTTTTCC -3' \\
\hline
\end{tabular}

GAPDH: glyceraldehyde-3-phosphate dehydrogenase; SOST: sclerostin; E1 1: podoplanin; DSPP: dentin sialophosphoprotein; OPG: osteoprotegerin; DMP-1: dentin matrix protein 1; ALPL: aplkaline phosphatase; OCN: osteocalcin. 
saline (DPBS, Invitrogen TM, Life Technologies, Gibco, Carlsbad, USA), cells were fixed in $4 \%$ formaldehyde solution with PBS for 20 minutes at room temperature. Next, cells were permeabilized using $0.1 \%$ Triton X-100 solution in PBS for 15 minutes, and blocked with a solution of BSA for 4 hours. Then, glass slides containing fixed cells were stained for 20 minutes at room temperature protected from light. Finally, cells were washed (2-3 times) in a phosphate-free buffer and visualized using the Leica TCS SP5 confocal microscope (Leica Microsystems, Wetzlar, Germany).

\section{Mineralization assay, in vitro}

The Von Kossa assay was used to access mineralization capacity of the selected clone. Cells were seeded $\left(5 \times 10^{4}\right.$ cells/well) in 24 -well plates and incubated for 24 hours in standard medium. Next, the medium was changed to mineralization induction medium ( $\alpha$-MEM added with 10\% FBS and induction supplements containing $50 \mathrm{mg} / \mathrm{mL}$ ascorbic acid, $10 \mathrm{mM} \beta$-glycerophosphate, and $10^{-5} \mathrm{M}$ dexamethasone), and the cultures were incubated for 28 days. The medium was changed every other day, and mineral nodules formation assessed after 21 days. Cells were washed with PBS and fixed in 100\% ethanol for 30 minutes. Then, every 5 minutes, an ethanol solution was exchanged at concentrations of 100, 90,70 , and $50 \%$. The ethanol was aspirated and the cells washed with distilled water. Silver nitrate 5\% solution was added to each well and incubated at $37^{\circ} \mathrm{C}, 5 \% \mathrm{CO}_{2}$ for 1 hour protected from light. Cells were then washed four times with distilled water, and after 24 hours under the light of a negatoscope, the mineral nodules were photographed. In addition to the Von Kossa assay, HCY23 cells were cultured as described above and the impact of osteogenic induction on the expression of DMP1, OPN, ALPL, and $O C N$ transcript levels assessed by qPCR at 3,7 , 14, and 21 days after osteogenic induction.

\section{Inorganic phosphate (Pi) treatment}

To determine the response pattern of HCY-23 to Pi treatment, a dose-response experiment was used $(0.05,0.25,0.5$, and $1 \mathrm{mM})$. Briefly, cells were seeded at $1.5 \times 10^{4}$ cells/well in 24-well cell culture plates and incubated for 24 hours (day 0) in culture media, containing $\alpha$-MEM, $2 \%$ FBS, $100 \mu \mathrm{g} / \mathrm{mL}$ streptomycin and $100 \mathrm{U} / \mathrm{mL}$ penicillin, at $37^{\circ} \mathrm{C}$ and $5 \% \mathrm{CO}_{2}$. After 24 hours, HCY-23 cells were treated or not with $\mathrm{Pi}$ at $0.05,0.25,0.5$ and $1 \mathrm{mM}$, and cell proliferation determined at $3,7,14$, and 21 days. Total cell number and viability were obtained using a hemocytometer and trypan blue, respectively. Next, cells were plated at $1.5 \times 10^{4}$ cells/well in 24-well cell culture plates and incubated for 24 hours in in culture media containing $\alpha$-MEM, 10\% FBS, $100 \mu \mathrm{g} / \mathrm{mL}$ streptomycin and 100 $\mathrm{U} / \mathrm{mL}$ penicillin, at $37^{\circ} \mathrm{C}$ and $5 \% \mathrm{CO}_{2}$. $\mathrm{HCY}-23$ cells were then treated or not with $\mathrm{Pi}$ at $0.05,0.25,0.5$ and $1 \mathrm{mM}$, and DMP1, OPN, ALPL and OCN transcript levels assessed by qPCR at $72 \mathrm{~h}$ after Pi treatment as described previously in this manuscript.

\section{Statistical analysis}

The effect of osteogenic conditions in gene expression profile was assessed by intergroup (student $t$-test) and intragroup (one-way ANOVA followed by the Bonferroni's post hoc test) analysis with significance level set at 5\% (GraphPad Prism 6.0, GraphPad, La Jolla, USA). Moreover, one-way ANOVA followed by the Bonferroni's post hoc test was used to determine the impact of Pi treatment on cell number and gene expression. Experiments were performed at least twice with comparable results and quantitative data is presented as mean \pm standard deviation (SD) of one representative experiment performed in triplicate, unless otherwise stated.

\section{RESULTS}

\section{Demographical findings and morphological characterization:}

A total of 24 heterogeneous cell populations was obtained from 13 teeth. About $37 \%$ of these populations was $D M P 1^{+}$, and were subsequently cloned using the ring-cloning technique. A total of 115 clones were obtained and characterized according to the expression of known cementocytes markers, e.g. DMP1, SOST, and E11. We found that only one clone, HCY-23, presented the expected gene expression signature (e.g., $\mathrm{DMP1}^{+}, \mathrm{SOST}^{+}, \mathrm{E}^{+} 1^{+}$, and $\left.\mathrm{DSPP}\right)$, and was then used for further characterization. Figure 1 illustrates the representative morphology of HCY-23 cells. 
A

\begin{tabular}{|c|c|}
\hline Genes & HCY-23 \\
\hline DMP-1 & + \\
\hline SOST & + \\
\hline E-1 1/GP38 & + \\
OPG & + \\
DSPP & - \\
\hline
\end{tabular}

\section{B}

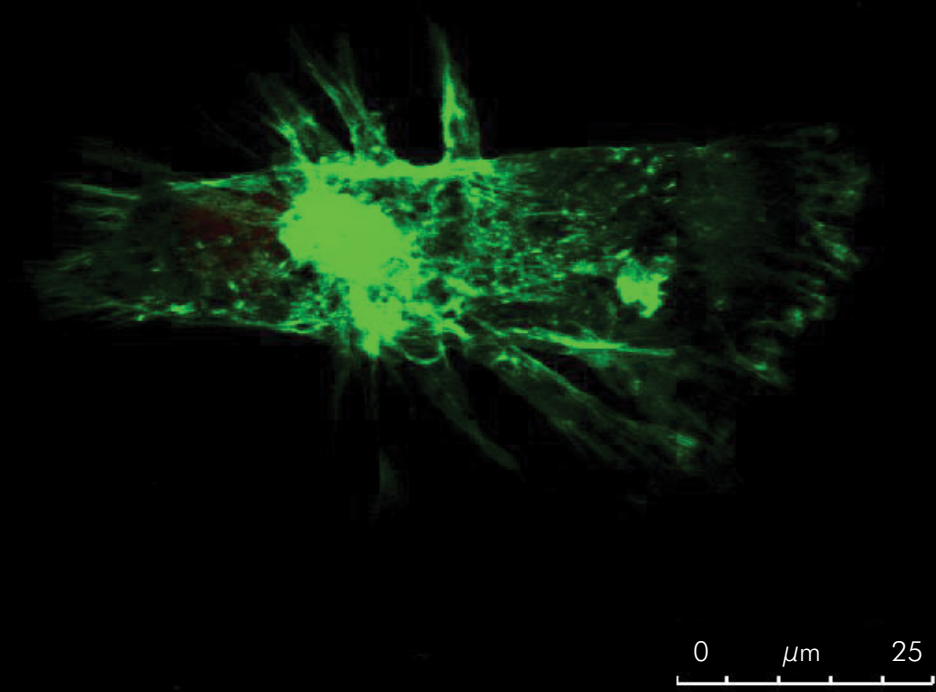

Figure 1. A) basal gene expression panel for HCY-23 cells; B) A representative confocal image of $\mathrm{HCY}-23$ cells stained by Phalloidin 488 and Syto Green for nucleus and cytoskeleton, respectively.

Control

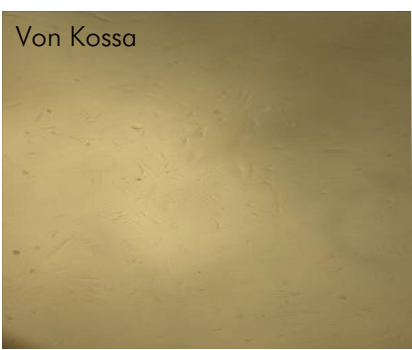

Xylenol orange
7 days
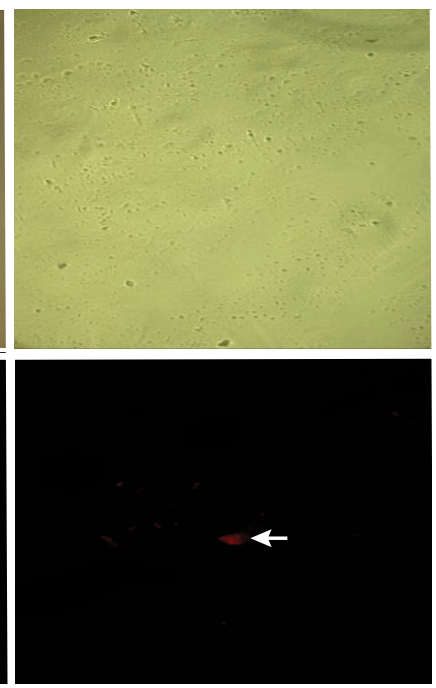

14 days
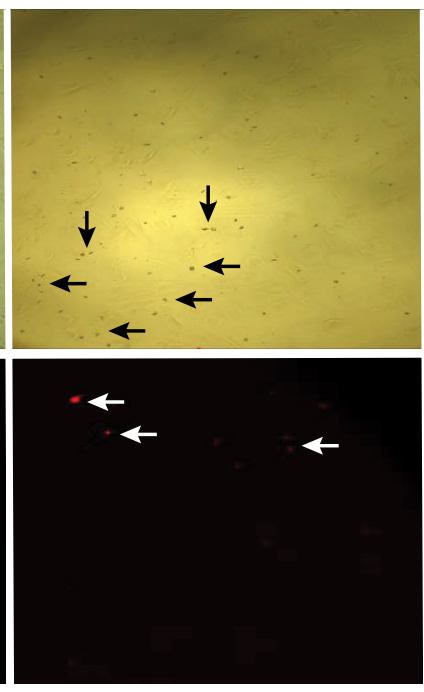

21 days

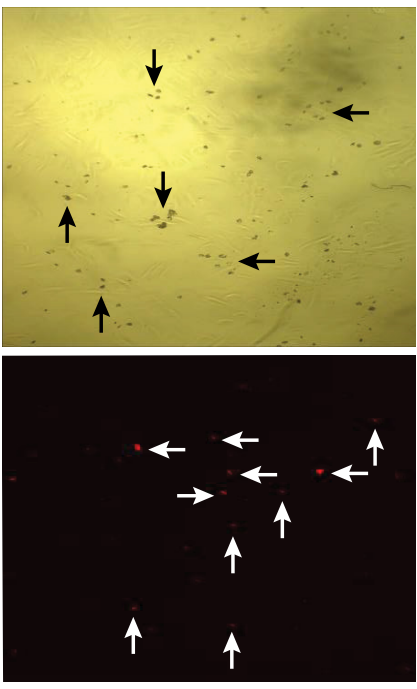

Figure 2. Representative illustration of the Von Kossa and xylenol orange assays at 7, 14, and 21 days after osteogenic induction. An increasing amount of mineral nodules is noted overtime (arrows).

\section{Osteogenic conditions modulate HCY-23 cells gene expression and induce mineral nodule formation in vitro}

An in vitro mineralization assay was performed to determine whether the human cementocyte-like cell line HCY-23 had the ability to promote mineral nodule formation. Mineralizing conditions were created, and we found that HCY-23 cells presented the ability to form small amounts of mineral nodules in vitro as early as 21 days after the induction was started (Figure 2). Mineral nodule formation was visually increased by 28 days (data not shown). In the 
current investigation, it was also assessed whether osteogenic conditions would affect DMP1, OPN, $A L P L$, and $O C N$ transcript levels at 3, 7, 14, and 21 days after treatment. Intergroup data analysis showed that osteogenic induction resulted in increased levels of transcripts for DMP1 and ALPL at 14 and 21 days, and $O C N$ at day $14(\mathrm{p}<0.05)$. In contrast, OPN mRNA levels were significantly diminished at day 14 and 21 after treatment $(p<0.05)$. Figure 3 illustrates gene expression findings under osteogenic conditions.

\section{HCY-23 are Pi responsive cells}

As dental cementum and cementoblasts have been shown to be highly sensitive to phosphate metabolism, we wanted to know whether the cementocyte-like cell line HCY-23 was affected by Pi treatment. First, using a dose-response experiment, we found that, at 3 and $5 \mathrm{mM}$, Pi was highly toxic to HCY-23, whereas at $1 \mathrm{mM}$ Pi did not affect cell viability up to 21 days as compared to the control group (data not shown). Guided by our preliminary findings, we decided to repeat the proliferation assay with Pi treatment at $0.05,0.25,0.5$, and $1 \mathrm{mM}$ up to 21 days. Data analysis demonstrated that cell number was increased in all the experimental groups compared to day 0 , with no difference among treatments $(\mathrm{p}>0.05)$ (Figure 4$)$. Intriguingly, we found that $\mathrm{Pi}$ alone resulted in a dose-dependent mineral deposition by HCY-23 cells (data not shown), and decided to examine whether Pi treatment would affect the expression of mineralization-associated genes. Our findings showed that Pi treatment significantly increased
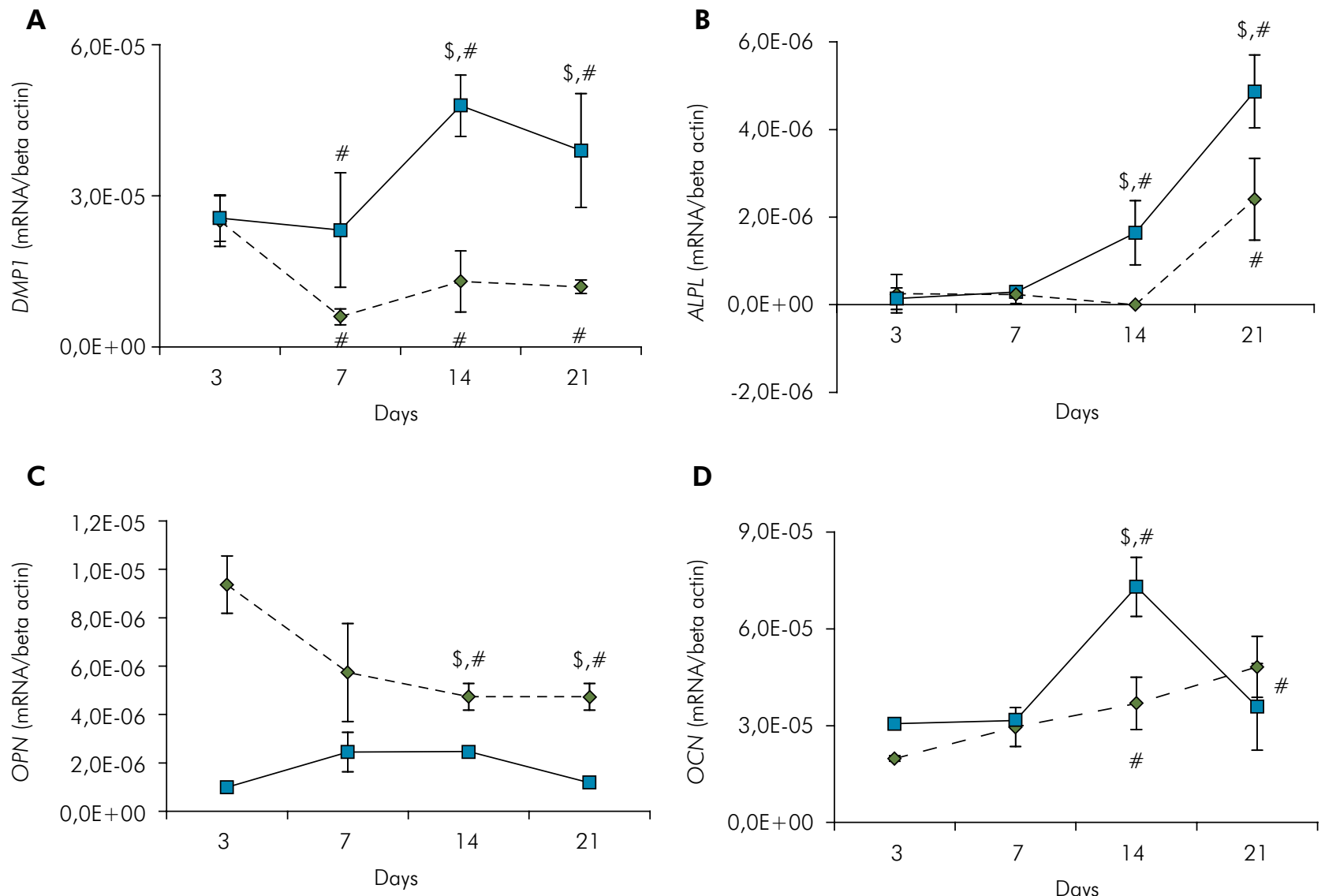

D

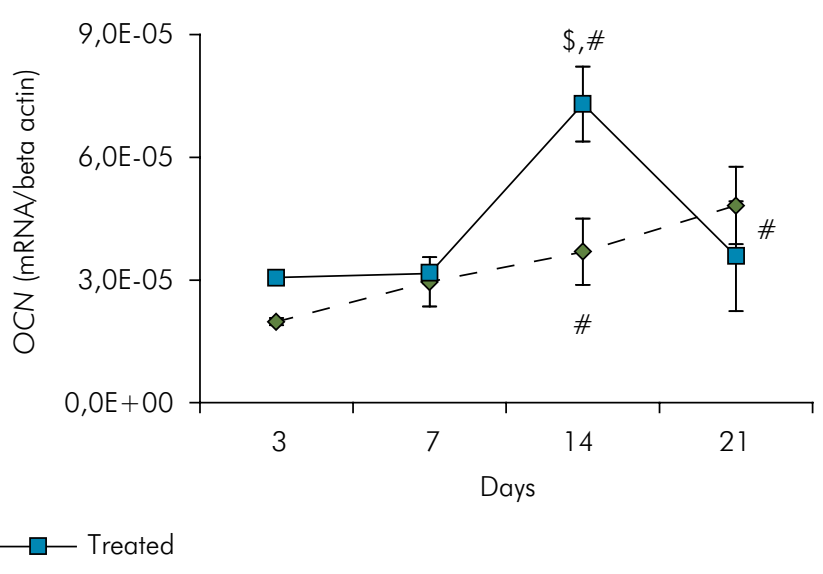

Figure 3. Effect of osteogenic induction on the expression of DMPI, $A L P L, O P N$, and $O C N$ at $3,7,14$, and 21 days after treatment (Pi-treated). ${ }^{*}$ Intragroup difference by one-way ANOVA followed by the Bonferroni test versus day 3 with alpha $=0.05 .{ }^{5}$ Intergroup difference by Student t-test with alpha $=0.05$. 
transcript levels for $D M P 1, O P N, O C N$, and $A L P L$ starting at doses as low as $0.25 \mathrm{mM}$ at three days after treatment $(\mathrm{p}<0.05)$ (Figure 5).

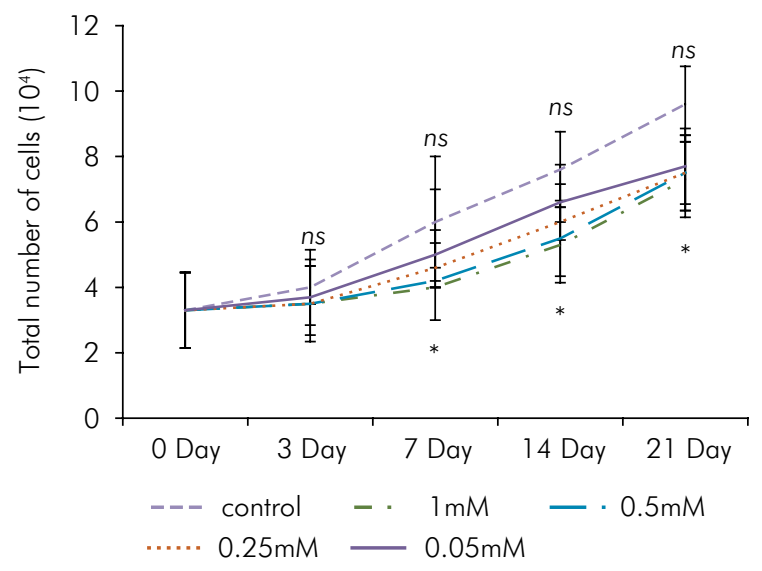

Figure 4. Effect of inorganic phosphate treatment (Pi) on the total number of cells at 3, 7, 14, and 21 days after treatment (Pi-treated). ns: non-significant intergroup differences by one-way ANOVA with alpha $=0.05$; *intragroup difference by one-way ANOVA followed by the Bonferroni test compared to day 0 for all the experimental groups with alpha $=0.05$.

\section{Discussion}

Teeth are made of two major parts, an enamelcovered crown and a cementum-covered root. Tooth development studies have focused on crown formation for several decades. However, a significant progress has been made in tooth root studies in the last two decades with the application of contemporaneous techniques such transgenic animals. ${ }^{15,16}$ Although dental cementum is now recognized as a critical tissue for tooth attachment, it was only discovered and characterized on human teeth after advances in microscopy almost a full century later than enamel and dentin. The functional relevance of dental cementum started to be appreciated after Black and others, in the late nineteenth and early twentieth centuries, reported detailed morphological data of periodontal tissues. These early studies on cementum laid the foundation for more advanced understanding of cementum ultrastructure, composition, development, physiology, disease, genetics, repair, and regeneration throughout the
A

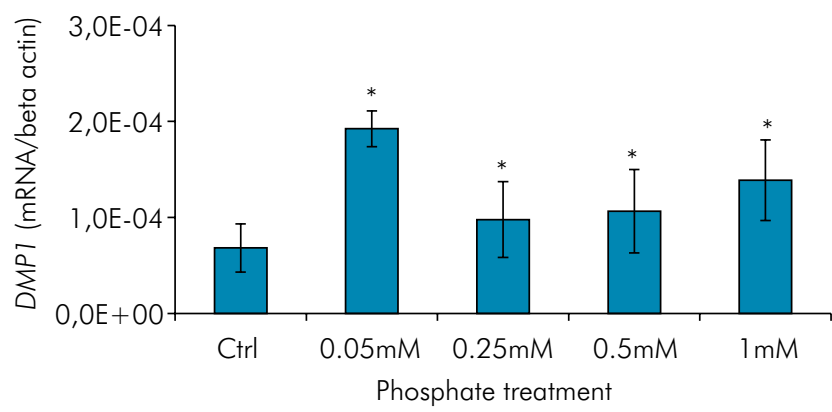

C

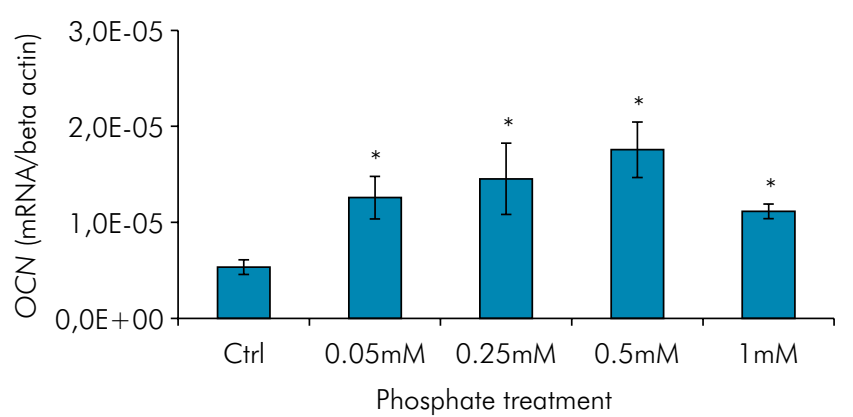

B

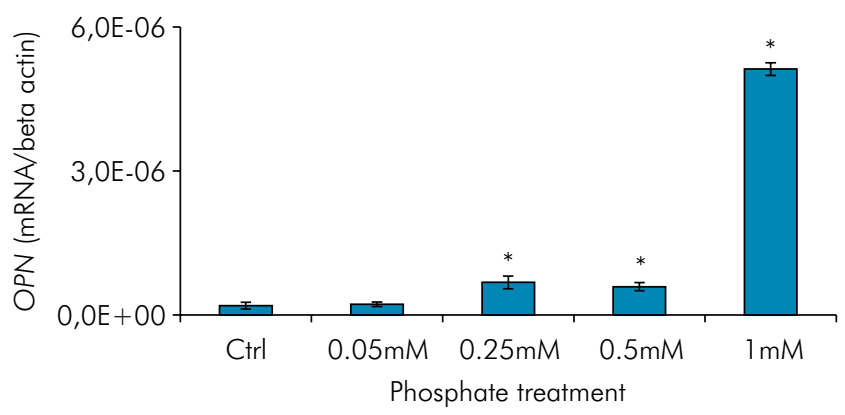

D

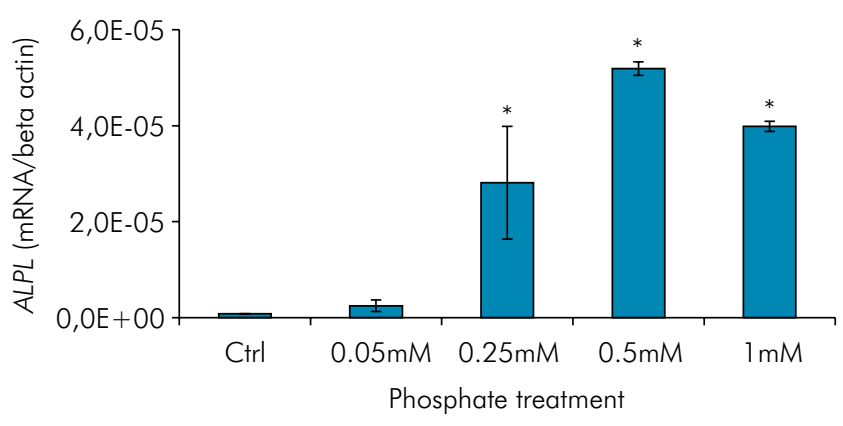

Figure 5. Effect of inorganic phosphate treatment (Pi) on the expression of DMPI, ALPL, OPN, and OCN at 3 days after treatment (Pi-treated). *Statistically different from the control group by one-way ANOVA followed by the Bonferroni test (alpha $=0.05)$. 
twentieth and into the twenty-first century. Foster ${ }^{17}$ has published a very nice and comprehensive description of the historical events from the discovery of the dental cementum to the recognition of its relevance as part of tooth-supporting structures. Dental cementum is now recognized as a mineralized tissue covering the tooth root, which functions in tooth attachment and posteruptive adjustment of tooth position. Two major types of dental cementum have been reported in human teeth, acellular cementum is located on the cervical parts of the tooth root and has been reported to be critical for tooth attachment, and the so called cellular cementum, which is located on the apical portions of the tooth root and in the furcation region and has a role in posteruptive adjustment of tooth position. During cellular cementum formation, cementoblasts, the tooth root lining cells, become entrapped in the cementoid matrix probably due to a rapid rate of extracellular matrix (ECM) deposition, and become cementocytes. Though, the event of cementogenesis is a critical aspect of periodontal homeostasis and regeneration, to date, it is not completely understood. Some fundamental questions remain regarding the process of cementogenesis, including the origin of cementoblastic cells, the factors directing cementum formation, and the potential functions for cementocytes during cementum formation and regeneration. In the current investigation, we investigated whether cementocytes have the potential to respond to endocrine signals and direct local cementum metabolism. We used a modified approach to obtain a primary cementocyte culture from human teeth that was comprehensively characterized regarding cell morphology, the expression of a panel of cementocyte-associated genes, their potential to produce mineral nodules in vitro and to respond to osteogenic induction and inorganic phosphate treatment. A cementocyte-like cell line was cloned (HCY-23), which presented a cementocyte compatible gene expression signature, including the expression of DMP1, SOST, E11, and OPG, whereas these cells did not express the odontoblast/dentin marker DSPP. Furthermore, we found that HCY-23 cells produced mineral-like nodules in vitro under differentiation conditions. Based on our results, HCY-23 cells were found to present a similar phenotype, including the production of mineral nodules in vitro and gene expression profile, to a previously isolated murine cementocyte-like cell line. ${ }^{18}$

Zhao et al. ${ }^{18}$ focused on the potential role of their cementocyte-like cell line to respond to a mechanical demand, in the current study, we examined whether HCY-23 cells were responsive to Pi treatment. Examination of cementum development in mouse models for Pi imbalance, including the tiptoe walking (ttw or Enpp-/-) mutant mouse carrying a mutation in the PC1 gene, the ank/ank transgenic mice, and the TNAP deficient mouse, revealed dental cementum to be exceptionally sensitive to $\mathrm{Pi}$ metabolism. 5,6,12 Likewise, human studies confirmed the tooth phenotype found in mouse models for Pi imbalance, ${ }^{19,20}$ and therefore, the demonstrated sensitivity of dental cementum to Pi metabolism in both human and mouse teeth establishes this as a well-conserved and fundamental biological process directing cementogenesis across species. Foster et al. ${ }^{21}$ explored the potential mechanisms involved with the impact of Pi metabolism in cementum development, and demonstrated the effect of Pi treatment in an immortalized murine cementoblast cell line (OCCM-30) behavior. They found that $\mathrm{Pi}$ at $5 \mathrm{mM}$ significantly upregulated genes including the SIBLING family genes Opn and Dmp1, whereas Ocn was found to be downregulated. In a later study, the same group ${ }^{5}$ defined the impact of an altered Pi environment on the composition of cementum ECM using immunohistochemistry and in situ hybridization approaches. They found that low extracellular levels of pyrophosphate (PPi) resulted in a marked increase of Dmp1 mRNA and Dmp1 protein levels, and transcript levels for Opn in the dental cementum ECM and cementoblasts. In addition, the authors reported a clear increase in Dmp1 message in cementocytes along the molar root. In line with these findings, our study demonstrated that Pi treatment may significantly impact on the expression of key genes regulating mineralization, including DMP1, OPN, OCN, and TNAP, and therefore suggests that cementocyte may play a role in the establishment of cementum phenotypes resulting from an altered phosphate environment 
during development and regeneration. Intriguingly, Pi treatment differentially regulates gene expression in cementoblasts versus cementocytes. While our findings of increased expression of DMP1 and OPN in cementocyte-like cells parallel with the increased expression of these differentiation/mineralization markers in cementoblasts ${ }^{5}$, our observation on OCN and TNAP mRNA levels are contrasting. We speculate that distinct functional commitment and differentiation state are responsible for the observed dissimilar response of cementoblasts and cementocytes to Pi. However, additional studies should be considered to further explore our hypothesis. The SIBLING proteins, such as DMP1 and OPN, standing for small integrin-binding ligand, N-linked glycoprotein, are components of the extracellular matrix of mineralized tissues including cementum, and evidence shows that these proteins play key roles in the mineralization of these tissues. ${ }^{22,23}$ In the present study, we found that an osteogenic induction also affected gene expression of HCY-23 cells. Similarly to Pi treatment, osteogenic induction significantly elevated DMP1,
TNAP, and OCN transcript levels, whereas OPN mRNA level was downregulated.

In summary, in addition to the already known effect of Pi on cementoblasts behavior, we showed for the first time that Pi regulates genes involved with $\mathrm{Pi} / \mathrm{PPi}$ metabolism like TNAP, and those identified to be important in the differentiation and mineralization, such as SIBLING family genes. To the best of our knowledge, this is the first time that a human-derived cementocyte-like cell line has been generated, comprehensively characterized and shown to be highly sensitive to Pi treatment. These findings will assist in elucidating the critical mechanisms involved in cementum formation and accelerate future dental research and clinical translation for the development of more predictable regenerative therapies.

\section{Acknowledgment}

This study was supported by the São Paulo State Research Foundation (Fapesp - grants \# 2015/07232-0 and 2015/06372-2), and by the National Council for Scientific and Technological Development [CNPq grant \# 304680/2014-1 (FHNJ)].

\section{References}

1. Bosshardt DD, Selvig KA. Dental cementum: the dynamic tissue covering of the root. Periodontol 2000. 1997 Feb;13(1):41-75. https://doi.org/10.1111/j.1600-0757.1997.tb00095.x

2. Foster BL, Somerman MJ, McCauley LK, Somerman MJ, editors. Mineralized Tissues in Oral and Craniofacial Science: Biological Principles and Clinical Correlates. 1st ed. Ames (IA): Wiley-Blackwell; 2012. pp. 169-92.

3. Bosshardt DD. Are cementoblasts a subpopulation of osteoblasts or a unique phenotype? J Dent Res. 2005 May;84(5):390-406. https://doi.org/10.1177/154405910508400501

4. Bosshardt DD, Sculean A. Does periodontal tissue regeneration really work? Periodontol 2000. 2009;51(1):208-19. https://doi.org/10.1111/j.1600-0757.2009.00317.x

5. Foster BL, Nagatomo KJ, Bamashmous SO, Tompkins KA, Fong H, Dunn D, et al. The progressive ankylosis protein regulates cementum apposition and extracellular matrix composition. Cells Tissues Organs. 2011;194(5):382-405. https://doi.org/10.1159/000323457

6. Foster BL, Ao M, Willoughby C, Soenjaya Y, Holm E, Lukashova L, et al. Mineralization defects in cementum and craniofacial bone from loss of bone sialoprotein. Bone. 2015 Sep;78:150-64. https://doi.org/10.1016/i.bone.2015.05.007

7. Zweifler LE, Patel MK, Nociti FH Jr, Wimer HF, Millán JL, Somerman MJ, et al. Counter-regulatory phosphatases TNAP and NPP1 temporally regulate tooth root cementogenesis. Int J Oral Sci. 2015 Mar;7(1):27-41. https://doi.org/10.1038/ijos.2014.62

8. Salmon CR, Tomazela DM, Ruiz KG, Foster BL, Paes Leme AF, Sallum EA, et al. Proteomic analysis of human dental cementum and alveolar bone. J Proteomics. 2013 Oct;91:544-55. https://doi.org/10.1016/i.jprot.2013.08.016

9. Bonewald LF. The amazing osteocyte. J Bone Miner Res. 2011 Feb;26(2):229-38. https://doi.org/10.1002/jbmr.320

10. Dallas SL, Prideaux M, Bonewald LF. The osteocyte: an endocrine cell ... and more. Endocr Rev. 2013 Oct;34(5):658-90. https://doi.org/10.1210/er.2012-1026

11. Stern AR, Stern MM, Van Dyke ME, Jähn K, Prideaux M, Bonewald LF. Isolation and culture of primary osteocytes from the long bones of skeletally mature and aged mice. Biotechniques. 2012 Jun;52(6):361-73. https://doi.org/10.2144/0000113876. 
12. Nociti FH Jr, Berry JE, Foster BL, Gurley KA, Kingsley DM, Takata T, et al. Cementum: a phosphate-sensitive tissue. J Dent Res. 2002 Dec;81(12):817-21. https://doi.org/10.1177/154405910208101204

13. Zweifler LE, Patel MK, Nocit FH, Wimer HF. Millán JL, Somerman M.J, Foster B.L. Counter-regulatory phosphatases TNAP and NPP1 temporally regulate tooth root cementogenesis. Int J Oral Sci. 2015 Mar;7(1):27-41. https://doi.org/10.1038/ijos.2014.62

14. Foster BL, Nagatomo KJ, Tso HW, Tran AB, Nociti FH Jr, Narisawa S, et al. Tooth root dentin mineralization defects in a mouse model of hypophosphatasia. J Bone Miner Res. 2013 Feb;28(2):271-82. https://doi.org/10.1002/ibmr.1767

15. Wang J, Feng JQ. Signaling pathways critical for tooth root formation. J Dent Res. 2017 Oct;96(11):1221-8. https://doi.org/10.1177/0022034517717478

16. Li J, Parada C, Chai Y. Cellular and molecular mechanisms of tooth root development. Development. 2017 Feb;144(3):374-84. https://doi.org/10.1242/dev.137216

17. Foster BL. On the discovery of cementum. J Periodontal Res. 2017 Aug;52(4):666-85. https://doi.org/10.1111/jre.12444

18. Zhao N, Nociti FH Jr, Duan P, Prideaux M, Zhao H, Foster BL, et al. Isolation and functional analysis of an immortalized murine cementocyte cell line, IDG-CM6. J Bone Miner Res. 2016 Feb;31(2):430-42. https://doi.org/10.1002/jbmr.2690

19. Martins L, Rodrigues TL, Ribeiro MM, Saito MT, Giorgetti AP, Casati MZ, et al. Novel ALPL genetic alteration associated with an odontohypophosphatasia phenotype. Bone. 2013 Oct;56(2):390-7. https://doi.org/10.1016/j.bone.2013.06.010

20. Thumbigere-Math V, Alqadi A, Chalmers NI, Chavez MB, Chu EY, Collins MT, et al. Hypercementosis associated with ENPP1 mutations and GACl. J Dent Res. 2018 Apr;97(4):432-21. https://doi.org/10.1177/0022034517744773

21. Foster BL, Nociti FH Jr, Swanson EC, Matsa-Dunn D, Berry JE, Cupp CJ, et al. Regulation of cementoblast gene expression by inorganic phosphate in vitro. Calcif Tissue Int. 2006 Feb;78(2):103-12. https://doi.org/10.1007/s00223-005-0184-7

22. Sun Y, Lu Y, Chen L, Gao T, D'Souza R, Feng JQ, et al. DMP1 processing is essential to dentin and jaw formation. J Dent Res. 2011 May;90(5):619-24. https://doi.org/10.1177/0022034510397839

23. Nagao M, Feinstein TN, Ezura Y, Hayata T, Notomi T, Saita Y, et al. Sympathetic control of bone mass regulated by osteopontin. Proc Natl Acad Sci USA. 2011 Oct;108(43):17767-72. https://doi.org/10.1073/pnas.1109402108 